Hull Emily (Orcid ID: 0000-0002-5577-6899)

\title{
Differences in Entheseal Changes in the Phalanges Between Ecotypes of Fennoscandian Reindeer
}

Emily Hull, University of Alberta*

Sirpa Niinimäki, University of Oulu

Anna-Kaisa Salmi, University of Oulu

*corresponding author

ehull@ualberta.ca

13-15 Tory Building

University of Alberta

Edmonton, Alberta

Canada T6G 2H4

\section{Abstract:}

The identification and life histories of the different subspecies and ecotypes of Rangifer tarandus (reindeer) in Fennoscandia are of great interest to zooarchaeologists, as this species is a keystone animal of the North. The barrenground Rangifer tarandus tarandus has historically had closer bonds with humans, as a herded and domestic animal. By contrast, the boreal Rangifer tarandus fennicus has been a prey animal with a more fraught relationship with humans. Identifying which of these ecotypes were present and interacting with humans at different points in history provides information not only of human economies and subsistence strategies, but of the life histories and behavioral patterns of the reindeer themselves. This study uses scoring of entheseal changes on the phalanges of these animals to investigate different mobility, foraging, and limb-use patterns between ecotypes. Our studies found both interesting differences in hoof use pattern between R.t. tarandus and R.t. fennicus that show that these ecotypes are both using their hooves differently, but in different patterns of fore- versus hindlimb use.

This article has been accepted for publication and undergone full peer review but has not been through the copyediting, typesetting, pagination and proofreading process which may lead to differences between this version and the Version of Record. Please cite this article as doi: 10.1002/oa.2897 


\section{Introduction}

Rangifer tarandus, the species which encompasses both reindeer and caribou, has been an integral animal for northern ecosystems and peoples. In Fennoscandia, the two native subspecies, or ecotypes of Rangifer tarandus have held different roles within human society. The more common barrenground Rangifer tarandus tarandus has shifted roles from prey to domestic animal, and in the modern era, all are domestic animals. By contrast, small populations of Rangifer tarandus fennicus represent the modern wild ecotype. While the possibility remains that R.t. fennicus may have contributed to current domestic herds through genetic introgression, the wild boreal R.t. fennicus has never been domesticated and has always been a prey animal. The reasons to investigate the differences between ecotypes come from the wealth of information that can come from the presence, absence, or proportions of different ecotypes present in an archaeological assemblage. These insights can then be used to more precisely explore animal life histories and the distinct forms of interactions reindeer had with humans in the past.

Separating these two subspecies in the archaeological record, however, comes with difficulties. Despite their different behaviors, habitats, and morphology, R.t. fennicus and R.t. tarandus overlap in size and in territory. Further, they are difficult to distinguish osteologically, especially in fragmentary and comingled assemblages where both subspecies may be present. In this study, entheseal changes in musculoskeletal attachments of the phalanges are compared between the two subspecies. We predict that the differing habitual activities of the two populations of reindeer generate distinct patterns of entheseal change in their feet. Identifying such differences will potentially aid in identifying archaeological specimens to subspecies. 


\section{Background}

Despite their similarities, the two ecotypes of Rangifer tarandus in Fennoscandia have very different lives. Today, all R.t. tarandus are domesticated, most managed in free-ranging herds divided by herding collectives. They naturally congregate in large herds, undergo long annual migrations, and are generally more docile and less skittish, perhaps due to their instinct to cluster together when faced with potential threats. They are part of the generally acknowledged "tundra ecotype" morphological pattern, being medium-sized reindeer with short legs. Despite being a "tundra ecotype," they are more accurately labelled as "barrenground," as they live not only on the alpine tundra of Fennoscandia, but on the Scandinavian montane located south of it.

R.t. fennicus, or wild forest reindeer, have diminished habitat areas in modern Finland, being restricted to small boreal and wetland areas in the mid-east of the country, near the Russian border. This subspecies is less social and less migratory and has a propensity to scatter and flee when threatened. Their habitual terrain is characterized by uneven topography and more dense foliage, leading this subspecies to graze as well as browse. Historically, R.t. fennicus were much more numerous and lived in the whole expanse of the boreal zone. Historically, wild reindeer of both types lived throughout the tundra, taiga, and boreal zones according to ecological niche (Luukko, 1954:111; Virrankoski, 1973:271-272; Lundmark, 1982:161).

Rangifer tarandus ecological niches are most often separated by groundcover (e.g., forest, tundra, heavy snow). While their ranges may overlap, the habitats and ecozones within those ranges are different; the two ecotypes primarily live in differing topographies. Reindeer interact habitually with these differing topographies in part through their feet, and it is expected that their feet should exhibit signs of change in relation to these differences in 
habitat and habitat-related activity. As a barrenground ecotype living in open, snowy tundra and taiga, we expect R.t.tarandus feet to show more pronounced adaptation for digging and foraging activities, especially in the forelimb. In contrast, R.t. fennicus, living in boreal zones with diverse topography, may show an adaptation to stability rather than specialized foraging.

As much human use of Rangifer tarandus bodies involves butchery practices that heavily fragment the head and major limb elements, phalangeal bones often are some of the only whole elements remaining in archaeological assemblages. Because of this, phalanges, especially the robust first phalanx (PI), make ideal candidates for archaeological assessment. Also, Rangifer tarandus are exceptionally well adapted to locomotion in snow and show extreme chionophilic adaptation, especially in the hoof (Telfer and Kelsall, 1971, 1984). The characteristics and composition of their snow-covered environments are integral to Rangifer tarandus foraging and locomotion, and therefore life history (Formozov, 1946). Because of this extreme environmental specialization, differences in ecological adaptations of the Rangifer foot, especially adaptation between ecotypes, is ripe for investigation.

\section{Reindeer Use and Domestication}

Reindeer herding in Fennoscandia most likely began at AD 800-1300 although some have posited that herding may have begun as early as 4700-4200 BC (Bergman et al., 2013; Hedman et al., 2015; Helskog, 2011). The exact mechanism by which reindeer hunting gave way to reindeer herding is a subject of great debate. (Sommerseth, 2011; Laufer, 1917; Mirov, 1945; Ingold, 1980; Willerslev et al., 2015). Larger-scale herding of tundra reindeer likely developed around AD 1500 from small scale reindeer keeping that formed part of diversified subsistence economies, and a broad aDNA change around this time period seems to reinforce this turning point (Bjørnstad et al., 2012). By around AD 1500, large scale reindeer pastoralism was practiced and formed the basis of economic systems (Bjørnstad et al., 2012; 
Bergman et al., 2013; Bjørklund, 2013; Hansen and Olsen, 2014: 195-206). This shift may have roots in the increasing trade, trade networks and emerging nation states of this period, which made closer control and individual ownership of individual reindeer economically advantageous (Hedman, 2003: 223-230; Odner, 2001; Vorren, 1974; 1977). Throughout this period of change for tundra reindeer, however, wild forest reindeer remained unmanaged and continued to be hunted by many groups (Tegengren, 1952; Kortesalmi, 2008: 23-24; Hansen and Olsen, 2014: 192-95).

Domestic reindeer in Fennoscandia, while all managed and owned in the modern era, do not show the same morphological changes by which many archaeologists may gage domestication in the archaeological record (Zeder et al., 2006; Zeder, 2012). Long-term reproductive selection by humans results in a series of morphological changes to an animal population. As reindeer have not been subject to the same degree and extent of reproductive restrictions in Fennoscandia, modern domestic reindeer remain morphologically analogous to their ancestral populations, which make wild and domesticated animals difficult to differentiate in the archaeological record (Puputti and Niskanen, 2009; Salmi et al., in press).

Both body size and composition differ somewhat between the two reindeer ecotypes. R.t. fennicus are larger animals with longer legs and more pronounced sexual size dimorphism, with male R.t. fennicus having an average body mass of $143 \mathrm{~kg}$, while the average male R.t. tarandus is only $128 \mathrm{~kg}$ (Banfield, 1961; Puputti and Niskanen, 2008; 2009: 154; Nieminen and Helle, 1980). Females show less distinction between ecotypes, with R.t. fennicus females weighing an average of $88 \mathrm{~kg}$, and R.t. tarandus females an average of $81 \mathrm{~kg}$. Much overlap in size exists between smaller R.t. fennicus and larger R.t. tarandus individuals, especially among females and between female R.t.fennicus and male R.t. tarandus. In cases where no diagnostic skeletal elements are present and sex is unknown, only the very largest individuals can be extrapolated to be R.t. fennicus, as sexual dimorphism 
complicates the differentiation of other skeletal materials. While R.t. fennicus have much longer legs than R.t. tarandus, they seemingly do not have proportionally larger hooves, so the phalanges of each ecotype cannot be identified by size alone. Such overlapping body sizes make skeletal elements difficult to identify to the subspecies level, particularly when they are fragmentary or multiple individuals are represented.

Reindeer meat and other reindeer products were traded at least from the Medieval period onwards, so it is impossible to say based on archaeological site location whether bones are of R.t. tarandus or R.t. fennicus. Both aDNA evidence and historical accounts point to a mosaic structure of reindeer use where both domestic R.t. tarandus and R.t. fennicus were utilized for different purposes in the same areas (Salmi and Heino, 2019). Complicating matters even more, few reliable ways of sexing most individual reindeer skeletal elements are presently available. This being so, archaeologists must look for other clues to the relationships of reindeer and humans in the archaeological record.

\section{Entheseal Changes}

Entheseal changes, also known as musculoskeletal stress markers (Villotte et al., 2016), are sites where muscles attach to bone either directly in fibrous enthesis or via cartilage in fibrocartilaginous enthesis (Benjamin et al., 1986, 2002; Villotte, 2006).

Variations in entheseal changes in human osteology are used to investigate subsistence strategies between groups, and division of labor between groups by social status and sex (e.g. Hawkey and Merbs, 1995; Churchill and Morris, 1998; Robb, 1998; Molnar, 2006, 2010). Utilization of entheseal changes to observe differences in activity patterns and/or intensity have recently been expanded to different animal species, where the methodology has been developed for reindeer (Niinimäki and Salmi, 2016) and horses (Binde et al., 2019). However, there are several methodological and etiological uncertainties involved (Jurmain et 
al., 2012). Several contributing factors have been identified, most notably age (Weiss, 2003; Niinimäki, 2011; Alves-Cardoso and Henderson, 2010; Michopoulou et al., 2015; Godde et al., 2018), regardless which entheseal observation method is used (Villotte et al., 2010; Milella et al., 2012; Acosta et al., 2017). In addition, body size has been identified as an issue where larger and heavier individuals have more developed entheses (Churchill and Morris, 1998; Niinimäki, 2011; Weiss et al., 2010; Michopoulou et al., 2015; Godde et al., 2018).

When considering how activity is reflected on entheses, there are two different viewpoints. On the other hand, activity effects are considered to result from overuse beyond the structural capacity of muscle-bone junction (Jurmain et al., 2012; Acosta et al., 2017). On the other, variation at an enthesis is considered subpathological where entheses modify to mechanical loading (Churchill and Morris, 1998; Lieverse et al., 2009; Niinimäki, 2012; Foster et al., 2014; Niinimäki and Salmi, 2016; Niinimäki et al., submitted). Depending on the above-mentioned viewpoints, research has focused on different features observed at an enthesis: bone resorption and bone formation. When overuse and thus pathological etiology is considered, studies focus on fibrocartilaginous entheses, specifically bone resorption as cortical defects in the form of erosion, porosity, and cavitation (cf. Drapeau, 2008, Mariotti et al., 2004, Milella et al., 2012; Henderson et al., 2013). When activity effects on entheseal changes are considered resulting from bone functional adaptation to mechanical loading, being thus subpathological, then focus is in the observation of bone formation or bone robusticity at an enthesis (Foster et al., 2014; Niinimäki and Salmi, 2014). It should be borne in mind that these two features at entheses, bone resorption and bone formation, may have different etiologies and should therefore be studied separately (Villotte and Knüsel, 2013; Foster et al., 2014). However, regarding reindeer fibrous and fibrocartilaginous entheses, both types of entheses - as well as bone formation and some bone resorption features - were found 
to covary with bone biomechanical properties, which are more readily accepted skeletal activity markers (Niinimäki et al. submitted).

Contribution of activity on entheseal changes remains heavily debated (Weiss, 2003; Molnar, 2006, 2010; Weiss et al., 2010; Alves-Cardso and Henderson, 2010; Niinimäki, 2011; Milella et al., 2012; Henderson et al., 2013; Michopoulou et al., 2015, 2017). In reindeer, bone formation at specific entheses has been observed to reflect activity. Freeranging reindeer digging for lichen from under the snow have more developed morphology in bone formation at attachments of several elbow flexor muscles, and zoo reindeer have more developed attachments of Subscapularis muscle, likely resulting from standing long periods of time with their shoulder bracing apparatus activated (Niinimäki and Salmi, 2016). Working and zoo reindeer have similar degree of variability at elbow flexor attachment sites compared to free-ranging reindeer, the latter having the most robust entheses (Niinimäki and Salmi, 2016; Salmi and Niinimäki, 2016). This likely results from the fact that zoo and draught reindeer are fed and need not dig for lichen. Finally, there is more considerable bone formation at the entheses of working reindeer compared to non-working reindeer (Salmi et al. 2020).

These prior studies on reindeer entheses as well as the supporting evidence from bone cross-sections (Niinimäki et al. manuscript) and geometric morphometric (Pelletier et al. submitted) studies encourage further development of methodology for observing changes at reindeer entheses on other bone elements. This study provides methodological reference categories for observing entheses at reindeer phalanges. This methodology is used to investigate differences in behavior and foraging strategy between the subspecies (Rangifer tarandus tarandus and Rangifer tarandus Fennicus) of Fennoscandian reindeer as apparent in their phalanges. 


\section{Materials and Methods:}

All analyzed individuals are adult specimens housed at the University of Oulu Biodiversity Unit. They included skeletal materials from both sexes of R.t. tarandus and R.t. fennicus whose remains include phalanges I $(\mathrm{n}=155)$, II $(\mathrm{n}=134)$, and III $(\mathrm{n}=133)$, with details provided in Table 1. The remains of R.t. tarandus far outnumber those of R.t. fennicus, especially in the cases of PII (second phalanx) and PIII (third phalanx) bones. The reason for the difference in sample size is two-fold. First, as R.t. fennicus is a protected species with diminishing numbers, its collection is highly restricted, and many of the available specimens were collected from deceased individuals partially dismembered by scavengers. Some of the small bones, especially PII and PIII, were not collected along with the rest of the body. Second, many of the deceased individuals collected had been in poor health, and many had pathologies of the feet, including extreme osteoarthritis, lipping and eburnation at articular surfaces, and occasional deformation of the bones as a whole, making them unsuitable for assessment. No animals of unknown provenance or subspecies designation were used. No hybrid, zoo-kept, or working animals were assessed in this study; all were free-ranging adults. Because the skeletal materials were collected with associated soft tissue, hides, and crania, often as well as antlers, all subspecies of specimens are known.

Mann Whitney U-tests were used during statistical analysis of differences between sites, as this test is robust when comparing samples of different sizes, and as the data was ordinal and not normally distributed. Each site of enthesis, while part of the foot as a whole, all are associated with individual tendons and ligaments that act on their own, so an independent sample test was appropriate in this case. Effect size was calculated by using Cohen's d, marking effect sizes to be small $(<0.2)$, moderate $(0.5)$ or large $(>0.8)$. This numerical value refers to the magnitude of difference between groups (Cohen, 1994, 1988; Sullivan and Feinn, 2012). 
Statistics were calculated using IMB SPSS, JASP, and jamovi software systems. All pathological and juvenile specimens were removed from the sample.

Before assessment could proceed, fore- and hindlimb phalanges were divided, as many of these were unlabelled in the sample. This division was based on metric assessment (Hull, 2019). Each phalanx was notated as fore- or hind, and multiple sites were scored on each phalanx, as shown in Figures $1,2, \& 3$. The data was then analysed via Mann-Whitney U-tests and exploratory t-tests to investigate differences at each site between subspecies, as well as differences at each site between fore- and hindlimb ECs within subspecies. In the methodology created for observing human entheseal changes, a critique ensued when the method published by Hawkey and Merbs (1995), originally intended for specific muscle and ligament attachments, was applied on other entheses (e.g. Churchill and Morris, 1998; Weiss, 2003, 2007; Molnar, 2006). This is a major issue against the application of method beyond investigated entheses. Variation present at a specific enthesis in a specific bone (and in a specific species) should not be generalized as an expression of variability of all entheses. Thus, for the reindeer phalanges entheses, the observation method developed for entheses of reindeer long bones cannot be applied. In creating categories of entheseal appearance, total variation present in the material for a specific enthesis was observed, and then this observed variation was divided in to three-grade scores (0-2). This follows the protocol and rationale as published in the original study for reindeer entheses in Niinimäki and Salmi (2016).

\section{Results:}

\section{Inter-Ecotype Differences:}

On PI, with both limbs pooled, the sites with statistically significant differences between R.t.tarandus and R.t.fennicus were A (U=893; $p<.001), \mathrm{B}(\mathrm{U}=810 ; p<.001), \mathrm{E}$ $(\mathrm{U}=787 ; p<.001)$, and $\mathrm{F}(\mathrm{U}=551 ; p<.001)$ (Table 2). Specifically, the scores for R.t. 
fennicus were consistently higher for those four entheses (Table 2). An ecotype-based comparison between fore- and hindlimb was also conducted and is discussed below. The effect size values for all statistically significant sites were moderately high $(A=0.781)$ to very high $(\mathrm{F}=1.266)$.

Pooled differences between ecotypes' PII bones are listed in Table 2. No sites were assessed as statistically different between the two ecotypes. Due to the small sample size of R.t. fennicus PII bones, an ecotype-based comparison between fore- and hindlimb was not feasible.

All PIII bones were pooled, as there is currently no method for consistently determining fore- from hindlimb. In the pooled sample, all sites showed significant differences (Table 2). These sites are insertion points for the deep flexor tendon (A (U=396; $p=0.045)$ and $\mathrm{C}(\mathrm{U}=380 ; p=0.033))$ and the long/common extensor tendon $(\mathrm{B}(\mathrm{U}=275 ; p$ =0.002)). In all cases, R.t. fennicus showed higher scores than R.t. tarandus (Table 2). The effect size values for all statistically significant sites were moderate $(A=0.650)$ to high $(B=$ $1.055)$.

When fore- and hindlimb PI of R.t. tarandus and R.t. fennicus were analysed separately, the results remained generally consistent, with one deviation (Table 3). Site D (forelimb: $\mathrm{U}=187.5 ; p=0.003$; hindlimb: $\mathrm{U}=340 ; p=.360$ ), exhibited significant difference in the forelimb, but not in the hind. This is the insertion site of the axial collateral proximal interphalangeal joint, or the insertion of the collateral pastern joint on the inner side of the hoof. In the forelimb, site D showed significantly lower EC scores among R.t.fennicus (mean $=1.000$, median $=1.000)$ than in R.t. tarandus $($ mean $=1.591$, median $=2.000)$ with a high effect size of -0.878 . In the hindlimb, site D showed no significant difference, with R.t. fennicus having a mean score of 0.917 and R.t.tarandus a mean score of 0.731 , with a small 
effect size of 0.251. Stress at this joint would occur during either flexion or extension of the medial and distal digits or during abduction of the toes.

\section{Intra-Ecotype Differences:}

R.t. tarandus shows significant differences between forelimb and hindlimb on sites D, $\mathrm{E}$, and F on PI (Table 4). While site $\mathrm{D}(\mathrm{U}=959 ; p<0.001)$, the medial interphalangeal collateral ligament, was more pronounced on the thoracic digits (thoracic mean $=1.591$, median $=2.000$; pelvic mean $=0.731$, median $=1.000$ ), sites $\mathrm{E}$ and $\mathrm{F}$, the proximal annular ligament insertion sites, were more pronounced on the hindlimb (E: $\mathrm{U}=1751 ; p=0.025$, thoracic mean $=0.697$, median $=1.000 ;$ pelvic mean $=0.985$, median $=1.000 ; \mathrm{F}: \mathrm{U}=1649 ; p$ $=0.007$, thoracic mean $=0.773$, median $=1.000 ;$ pelvic mean $=1.134$, median $=1.000)$. In R.t. fennicus, only site $\mathrm{E}(\mathrm{U}=33 ; p=0.021)$ showed a significant difference, with thoracic mean $=1.182$, median $=1.000$ and pelvic mean $=1.833$, median $=2.000$, with a high effect size of -1.105 . This shows that while R.t. fennicus may show more flexion in the hind digits than in the digits of the forelimb, this dichotomy between the use of the fore- and hindlimb is less distinct than in R.t. tarandus.

When analysing PII forelimb versus hindlimb, complete analysis of R.t. fennicus phalanges were hampered by a lack of samples. In R.t. tarandus, the pattern of differences in EC development between in the fore- and hindlimb continues to be present. On site A (U= $1557 ; p=0.036$ ), the pelvic limb showed higher EC scores (thoracic mean $=1.000$, median $=$ 1.000; pelvic mean $=1.286$, median $=1.000 ;$ effect size $=0.388)$, while on site $\mathrm{C}(\mathrm{U}=1556$; $p=0.028)$, the thoracic limb showed higher EC scores $($ thoracic mean $=1.532$, median $=$ $1.000 ;$ pelvic mean $=1.222$, median $=1.000 ;$ effect size $=-0.399)$.

In summary, R.t. fennicus showed generally higher scores overall, while R.t. tarandus exhibited a higher diversity of scores between fore- and hindlimb. This pattern suggests that 
the two ecotypes use their limbs in different manners, and these differences manifest in visible ways within their feet

\section{Discussion:}

Analysis has shown that some bones of the reindeer foot offer more information than others. Because of their positions as the beginning and end of the digit, PI and PIII show more marked entheseal changes between ecotypes. This makes anatomical sense, as the complex divisions and recombination of ligaments and tendons, as well as the stabilizing interdigital cruciate ligament of PII, protect this bone from the stressors placed on the proximal and distal phalanges (Hull et al., in review). While PIII shows consistently variable EC development, PI offers additional information, as forelimb bones can be decisively separated from hindlimb bones (Hull, 2019). This means that PI fore- and hindlimb ECs can be analysed separately, and the differences in development can be assessed between ecotype.

Using pooled samples to compare differences between ecotypes, significant differences in EC development are found on four attachment sites on PI associated with flexion and extension. No sites showed significant differences on PII. All three sites analysed on PIII show significant differences between ecotypes, and these three sites are also associated with tendinous insertion points responsible for flexion and extension. The interecotype comparisons between pooled PII and PIII must be viewed conservatively however, as the small number of R.t. fennicus samples for these elements make these analyses less comprehensive than those of PI. While the size differences between R.t. fennicus and R.t. tarandus may have some effect on entheseal development, it is important to note that our study shows that some, but not all, entheseal sites show significant differences; R.t. fennicus do not show more entheseal development in all cases or on all sites. 
When PI was separately assessed by both ecotype and limb, statistically significant sites remained the same, with the addition of the axial collateral metacarpophalangeal ligament on the thoracic limb (Tables 2,3). When the thoracic and pelvic limbs were analysed between members of the same ecotype, an interesting pattern emerged. While only one site of significant difference in ECs was found between the fore- and hindlimb PIs of R.t. fennicus (Table 2), R.t. tarandus showed differences in three sites on PI (Table 3). While the small number of R.t. fennicus PII phalanges $(\mathrm{n}=9)$ make comprehensive statistics impossible, exploratory t-tests suggest that there are no significant differences between any sites, while R.t. tarandus show significant differences between fore- and hindlimb on two sites (Table 4). The most suggestive of these, sites A and C, or the extensor and flexor tuberosities, were calculated on the small number of R.t. fennicus specimens and showed no difference between limbs:

\section{Inter-ecotype differences:}

In the pooled analysis of PI, R.t. fennicus had higher EC scores than R.t. tarandus on sites A, B, E, and F. The sites A and B translate to the axial and abaxial collateral metacarpo/metatarsophalangeal ligaments, which move with the flexion and extension of PI. These ligaments also function to stabilize the articulation between the metapodial and PI. Sites E and $\mathrm{F}$ are the insertion sites of each side of the distal annular ligament of PI. This ligament binds the flexor tendons to PI, creating a sheath that both allows mobility but stabilizes the tendons against PI. When the digits are flexed, this creates pressure against the distal annular ligaments, pulling them away from PI and causing stress at the insertion site.

Several interpretations may explain the difference in EC development between R.t. tarandus and R.t.fennicus. One important factor may be their differing habitats. R.t. fennicus are forest dwellers who will often traverse multiple ecozones in search of food and water. 
This includes wading in swamps and wetlands, climbing up rocky fells and cliffs, and dodging fallen trees and underbrush. This may produce more wear and tear on their feet as they adapt to changing ground conditions. By contrast, the barrenground R.t. tarandus are subject to far less diversity of habitat, with heavy snowdrifts often cushioning their movements in winter. These differences could account for the differences in ECs in the phalanges.

Behavioral adaptation and human habituation may account for additional difference. All R.t. fennicus are wild, and are by nature skittish and wary, fleeing at any signs of predators. The R.t. tarandus in the sample, while all free-range, are domestic animals who have some contact with humans and respond to predators by grouping, rather than dispersing. The heavy flight instinct of R.t. fennicus could lead to regular abrupt, powerful movements in the hooves that would in turn lead to entheseal development. The domestic R.t. tarandus likely experiences far fewer such abupt movements, resulting in lower EC scores.

\section{Intra-ecotype differences:}

While the differences in patterns between the ecotypes may allow zooarchaeologists to more easily identify the subspecies of reindeer in an assemblage, the differences in patterns between fore- and hindlimb within groups may shed light on different niche adaptations and behaviors. R.t. tarandus shows significantly different EC scores between fore- and hindlimb, while R.t. fennicus shows only slight differences between the two limbs. R.t. tarandus shows significant differences between sites D, E, and F on PI, two of which correspond to the insertions for the proximal annular ligaments, which are the primary sites holding the heavy flexor tendons to the digits. These sites combined suggest that there was more overall flexion in the hindlimb, whereas there appears to be more interdigital movement between PI and PII, 
as well as more abduction in the forelimb. In R.t. fennicus, only site $\mathrm{E}(p=0.021)$ showed a significant difference. This indicates that while R.t. fennicus also shows more flexion in the hind digits, this dichotomy between the use of the fore- and hindlimb is less distinct. Our analysis suggests that while R.t. fennicus have more entheseal development in general, R.t. tarandus have more differentiated entheseal development. We propose that while R.t. fennicus may use the tendons and ligaments in their feet more, they do so holistically, with both limbs being subject to similar amounts and kinds of physical stressors. R.t. tarandus use different limbs for different purposes, leading to different entheseal changes between the limbs.

When analysing PII, complete analysis of R.t. fennicus phalanges were hampered by the small number of samples. In R.t. tarandus, however, we see evidence of a continued divergence between activity pattern in the fore and hindlimb, as sites $\mathrm{A}$ and $\mathrm{C}$, the extensor and flexor tuberosities respectively showed significant differences. This difference is interesting because on site A, the extensor tuberosity, the pelvic limb showed higher EC scores, while on site $\mathrm{C}$, the flexor tuberosity, the thoracic limb showed higher EC scores. The flexor tuberosity of PII is the insertion point of the superficial digital flexor and is congruent with the high thoracic EC scores of the medial interphalangeal collateral ligament of PI, as the development of both these sites are suggestive of repetitive flexion at the PI-PII interphalangeal joint (Hull et al. in review). This suggests that while both ecotypes flex their entire hindlimbs more habitually, R.t. tarandus, at least, flexes the smaller joints of the hooves in the forelimb, creating a scoop-shape out of their hoof. This may be consistent with more habitual pawing at the ground, digging, or using the forelimb hoof for foraging activities. If larger sample sizes confirm that this is untrue for R.t. tarandus, this may be an indication of less digging for forage, due to either more habitual browsing or less snow cover hampering foraging efforts. 


\section{Limitations:}

While the data shows a convincing pattern of differing hoof use between ecotypes of Rangifer tarandus, several limitations to this study must be discussed. First, the effect of sex on hoof use could not be analysed, primarily to the small sample of R.t. fennicus. Second, the size of the animals themselves may have affected levels of entheseal change. While R.t. fennicus are larger-bodied and had generally higher EC scores, they did not have universally higher EC scores, which suggests that size is not the only factor affecting the EC score differences between ecotype. Last, the age of each individual must be taken into account. While all specimens were adults, their exact age is unknown. A mitigating factor, however, is the removal of any specimens who showed age-related disease such as osteoarthritis. This is one way that senescent individuals may have been removed from the sample.

\section{Conclusion:}

The data shows that there are significantly different EC patterns between the ecotypes of R.t. tarandus and R.t.fennicus, which may be caused by several factors. While the specific factors are not directly identifiable, the observed differences strongly suggest that there are significant behavioral, mobility, and/or foraging behaviors between these populations. The identification of these consistent differences has implications for studies of zooarchaeology, paleoecology, and domestication studies.

In zooarchaeological assemblages, R.t. tarandus and R.t. fennicus remains are nearly impossible to separate, especially in disarticulated and co-mingled remains. The differences in the ECs of the phalanges shown in this study present an additional tool for zooarchaeologists to determine whether R.t.fennicus, R.t. tarandus, or both, are present in an assemblage. Such identifications can, in turn, help establish which hunting, herding, or combined strategies were employed in the past. Fluctuation in the presence of the ecotypes in 
different areas of Finland is an additional clue to human interference in reindeer lives. For example, with the increase in herded reindeer, R.t. tarandus have shifted further south than their natural habitat, moving into the boreal zone, as they continue to do today (Kortesalmi, 2008: 29-63). A shift in faunal assemblage composition from R.t. fennicus to R.t. tarandus also may indicate a shift from hunting to herding, and a combined assemblage may indicate a mixed subsistence strategy.

Such subspecies identifications can likewise have implications for paleoecology. The presence of one or both of ecotypes may help show habitat and environmental change and elucidate shifting ranges of ecotypes. Habitat and range change is of increased importance in the current era, where climate change affects the ranges and viability of these animals. Understanding their historic habitats and environments helps us not only understand human history, but the species history of Rangifer tarandus in Fennoscandia.

\section{Conflicts of Interest:}

The authors have no conflicts of interest to report.

\section{Acknowledgements:}

We would like to acknowledge funding from the European Research Council (756431) and the Academy of Finland (285774). Additional funded was provided by a grant from UAlberta North. We would also thank the Zoological Museum of the Biodiversity Unit at the University of Oulu and especially Tuula Pudas for help with accessing the collection. In addition, many thanks to Dr. Robert Losey for his assistance on this project.

\footnotetext{
Supplementary Materials: Appendix S1: Scoring Criteria
} 


\section{Bibliography:}

Acosta, M. A., Henderson, C. Y., and Cunha, E. (2017). The Effect of Terrain on Entheseal Changes in the Lower Limbs. International Journal of Osteoarchaeology, 27(5), 828-838. doi: 10.1002/oa.2597

Banfield, A. W. (1961). Revision of the Reindeer and Caribou, Genus Rangifer. (No.66) Ottawa: Queen's Printer.

Benjamin, M., Evans, E. J., and Copp, L. (1986). The histology of tendon attachments to bone in man. Journal of anatomy, 149, 89.

Benjamin, M., Kumai, T., Milz, S., Boszczyk, B. M., Boszczyk, A. A., and Ralphs, J. R. (2002). The skeletal attachment of tendons - tendon 'entheses'. Comparative Biochemistry and Physiology Part A: Molecular and Integrative Physiology, 133(4), 931-945.

Bjørnstad, G., Flagstad, Ø., Hufthammer, A. K., and Røed, K. H. (2012). Ancient DNA reveals a major genetic change during the transition from hunting economy to reindeer husbandry in northern Scandinavia. Journal of Archaeological Science, 39(1), 102-108. doi: 10.1016/j.jas.2011.09.006

Churchill, S. E., and Morris, A. G. (1998). Muscle marking morphology and labour intensity in prehistoric Khoisan foragers. International Journal of Osteoarchaeology, 8(5), 390-411. doi: 10.1002/(sici)1099-1212(1998090)8:5<390::aid-oa435>3.0.co;2-n

Cohen, J. (1994). The earth is round ( $\mathrm{p}<$.05). American Psychologist, 49(12), 997-1003. doi: $10.1037 / 0003-066 x .49 .12 .997$

Formozov, A. N. (1964). Snow cover as an integral factor of the environment and its importance in the ecology of mammals and birds. Edmonton, Alta.: Boreal Institute for Northern Studies, the University of Alberta.

Foster, A., Buckley, H., and Tayles, N. (2012). Using Enthesis Robusticity to Infer Activity in the Past: A Review. Journal of Archaeological Method and Theory, 21(3), 511-533. doi: 10.1007/s10816-012-9156-1

Godde, K., Taylor, R. W., and Gutierrez, C. (2018). Entheseal changes and demographic/health indicators in the upper extremity of modern Americans: Associations with age and physical activity. International Journal of Osteoarchaeology, 28(3), 285-293. doi: $10.1002 /$ oa.2653

Hawkey, D. E., and Merbs, C. F. (1995). Activity-induced musculoskeletal stress markers (MSM) and subsistence strategy changes among ancient Hudson Bay Eskimos. International Journal of Osteoarchaeology, 5(4), 324-338. doi: 10.1002/oa.1390050403

Hedman, S.-D., Olsen, B., and Vretemark, M. (2015). Hunters, herders and hearths: interpreting new results from hearth row sites in Pasvik, Arctic Norway. Rangifer, 35(1), 124. doi: $10.7557 / 2.35 .1 .3334$ 
Helskog, K. (2011). Reindeer corrals 4700-4200 BC: Myth or reality? Quaternary International, 238(1-2), 25-34. doi: 10.1016/j.quaint.2010.10.001

Henderson, C. Y., Mariotti, V., Pany-Kucera, D., Villotte, S., and Wilczak, C. (2012). Recording Specific Entheseal Changes of Fibrocartilaginous Entheses: Initial Tests Using the Coimbra Method. International Journal of Osteoarchaeology, 23(2), 152-162. doi: 10.1002/oa.2287

Hull, E. H. (2019). Metric and non-metric guides for the determination between fore- and hindlimb phalanges of Rangifer tarandus. Rangifer, 39(1), 11-26. doi: 10.7557/2.39.1.4630

Hull, E. H., Semeniuk M., Niinimäki S., and Puolakka H-L. Tendons and Ligaments of the Rangifer tarandus metapodial and hoof. In review in Polar Biology.

Ingold, T. (2007). Hunters, pastoralists, and ranchers: reindeer economies and their transformations. Cambridge: Cambridge Univ. Pr.

Jurmain, R., Cardoso, F. A., Henderson, C., and Villotte, S. (2012). Bioarchaeologys Holy Grail: The Reconstruction of Activity. A Companion to Paleopathology, 531-552. doi: 10.1002/9781444345940.ch29

Kortesalmi, J. J. (2008). Poronhoidon synty ja kehitys Suomessa. Helsinki: Suomalaisen Kirjallisuuden Seura.

Laufer, B. (1917). The reindeer and its domestication. Lancaster, PA: American Anthropological Assoc.

Lieverse, A. R., Bazaliiskii, V. I., Goriunova, O. I., and Weber, A. W. (2009). Upper limb musculoskeletal stress markers among middle Holocene foragers of Siberias Cis-Baikal region. American Journal of Physical Anthropology, 138(4), 458-472. doi:

10.1002/ajpa.20964

Lundmark, L. (1982). Uppbörd, utarmning, utveckling: det samiska fångstsamhällets övergång till rennomadism i Lule lappmark (Vol. 14). Arkiv för studier i arbetarrörelsens historia.

Luukko, A. (1954). Pohjois-Pohjanmaan ja Lapin historia. Oulu: Oy. Liiton kirjapaino.

Mariotti, V., Facchini, F., and Giovanna Belcastro, M. (2004). Enthesopathies-proposal of a standardized scoring method and applications. Collegium antropologicum, 28(1), 145-159.

Michopoulou, E., Nikita, E., and Henderson, C. Y. (2016). A Test of the Effectiveness of the Coimbra Method in Capturing Activity-induced Entheseal Changes. International Journal of Osteoarchaeology, 27(3), 409-417. doi: 10.1002/oa.2564

Michopoulou, E., Nikita, E., and Valakos, E. D. (2015). Evaluating the efficiency of different recording protocols for entheseal changes in regards to expressing activity patterns using archival data and cross-sectional geometric properties. American Journal of Physical Anthropology, 158(4), 557-568. doi: 10.1002/ajpa.22822 
Milella, M., Belcastro, M. G., Zollikofer, C. P., and Mariotti, V. (2012). The effect of age, sex, and physical activity on entheseal morphology in a contemporary Italian skeletal collection. American Journal of Physical Anthropology, 148(3), 379-388. doi:

10.1002/ajpa. 22060

Mirov, N. T. (1945). Notes On The Domestication Of Reindeer. American Anthropologist, 47(3), 393-408. doi: 10.1525/aa.1945.47.3.02a00030

Molnar, P. (2008). Patterns of physical activity and material culture on Gotland, Sweden, during the Middle Neolithic. International Journal of Osteoarchaeology. 20(1), 1-14. doi: 10.1002/oa. 1000

Molnar, P. (2005). Tracing prehistoric activities: Musculoskeletal stress marker analysis of a stone-age population on the Island of Gotland in the Baltic sea. American Journal of Physical Anthropology, 129(1), 12-23. doi: 10.1002/ajpa.20234

Nieminen, M., and Helle, T. (1980, January). Variations in body measurements of wild and semi-domestic reindeer (Rangifer tarandus) in Fennoscandia. In Annales Zoologici Fennici (pp. 275-283). Finnish Academy of Sciences, Societas Scientiarum Fennica, Societas pro Fauna et Flora Fennica and Societas Biologica Fennica Vanamo.

Niinimäki, S., and Salmi, A.-K. (2014). Entheseal Changes in Free-Ranging Versus Zoo Reindeer-Observing Activity Status of Reindeer. International Journal of Osteoarchaeology, 26(2), 314-323. doi: 10.1002/oa.2423

Niinimäki, S. (2009). What do muscle marker ruggedness scores actually tell us? International Journal of Osteoarchaeology, 21(3), 292-299. doi: 10.1002/oa.1134

Niinimäki, S. (2012). The relationship between musculoskeletal stress markers and biomechanical properties of the humeral diaphysis. American Journal of Physical Anthropology, 147(4), 618-628. doi: 10.1002/ajpa.22023

Niinimaki, S., Puolakka, H., Salmi, A.-K. (2019). Covariation bone biomechanics and entheseal changes in reindeer long bones - implication of activity? American Journal of Physical Anthropology, 168:177-177.

Niinimäki, S., Salmi, A.-K. (Submitted). Covariation between entheseal changes and crosssectional properties of reindeer long bones - considering bone functional adaptation as partial contributing factor. Journal of Archaeological Science: Reports.

Niinimäki, S., Härkönen, L., Puolakka, H., Berg, van den M., Salmi, A.-K. (Manuscript). Cross-sectional properties of reindeer long bones and metapodials allow identification of activity patterns.

Pelletier, M., Kotiaho, A., Niinimäki. S., Salmi, A.-K. (Submitted). Identifying early stages of reindeer domestication in the archaeological record: a 3D morphological investigation on forelimb bones of modern populations from Fennoscandia. Archaeological and Anthropological Sciences. 
Puputti, A.-K., and Niskanen, M. (2008). The estimation of body weight of the reindeer (Rangifer tarandusL.) from skeletal measurements: preliminary analyses and application to archaeological material from 17th- and 18th-century northern Finland. Environmental Archaeology, 13(2), 153-164. doi: 10.1179/174963108x343272

Puputti, A.-K., and Niskanen, M. (2009). Identification of semi-domesticated reindeer (Rangifer tarandus tarandus, Linnaeus 1758) and wild forest reindeer (R.t. fennicus, Lönnberg 1909) from postcranial skeletal measurements. Mammalian Biology, 74(1), 49-58. doi: 10.1016/j.mambio.2008.03.002

Robb, J. E. (1998). The interpretation of skeletal muscle sites: a statistical approach. International Journal of Osteoarchaeology, 8(5), 363-377. doi: 10.1002/(sici)10991212(1998090)8:5<363::aid-oa438>3.0.co;2-k

Salmi, A.-K., and Niinimäki, S. (2016). Entheseal changes and pathological lesions in draught reindeer skeletons - Four case studies from present-day Siberia. International Journal of Paleopathology, 14, 91-99. doi: 10.1016/j.ijpp.2016.05.012

Salmi. A.-K, Niinimäki, S., Pudas, T. (2020). Identification of working reindeer using palaeopathology and entheseal changes. International Journal of Paleopathology.

Sommerseth, I. (2011). Archaeology and the debate on the transition from reindeer hunting to pastoralism. Rangifer, 31(1), 111. doi: 10.7557/2.31.1.2033

Sullivan, G. M., and Feinn, R. (2012). Using Effect Size-or Why the P-Value Is Not Enough. Journal of Graduate Medical Education, 4(3), 279-282. doi: 10.4300/jgme-d-1200156.1

Telfer, E. S., and Kelsall, J. P. (1979). Studies of morphological parameters affecting ungulate locomotion in snow. Canadian Journal of Zoology, 57(11), 2153-2159. doi: $10.1139 / \mathrm{z} 79-283$

Telfer, E. S., and Kelsall, J. P. (1984). Adaptation of Some Large North American Mammals for Survival In Snow. Ecology, 65(6), 1828-1834. doi: 10.2307/1937779

Villotte, S. (2006). Connaissances médicales actuelles, cotation des enthésopathies: nouvelle méthode. Bulletins et Mémoires de la Société d'Anthropologie de Paris, (18 (1-2)), 65-85.

Villotte, S., Castex, D., Couallier, V., Dutour, O., Knüsel, C. J., and Henry-Gambier, D. (2010). Enthesopathies as occupational stress markers: evidence from the upper limb. American Journal of Physical Anthropology: The Official Publication of the American Association of Physical Anthropologists, 142(2), 224-234.

Villotte, S., and Knüsel, C. J. (2012). Understanding Entheseal Changes: Definition and Life Course Changes. International Journal of Osteoarchaeology, 23(2), 135-146. doi: 10.1002/oa.2289

Villotte, S., Assis, S., Cardoso, F. A., Henderson, C. Y., Mariotti, V., Milella, M., ... Jurmain, R. (2016). In search of consensus: Terminology for entheseal changes (EC). International Journal of Paleopathology, 13, 49-55. doi: 10.1016/j.ijpp.2016.01.003 
Virrankoski, P. (1973). Pohjois-Pohjanmaan ja Lapin historia III. Pohjois-Pohjanmaa ja Lappi 1600-luvulla. Oulu, Pohjois-Pohjanmaan, Kainuun ja Lapin maakuntaliittojen yhteinen historiatoimikunta.

Weiss, E., Corona, L., and Schultz, B. (2010). Sex differences in musculoskeletal stress markers: Problems with activity pattern reconstructions. International Journal of Osteoarchaeology, 22(1), 70-80. doi: 10.1002/oa.1183

Weiss, E. (2003). Understanding muscle markers: Aggregation and construct validity. American Journal of Physical Anthropology, 121(3), 230-240. doi: 10.1002/ajpa.10226

Willerslev, R., Vitebsky, P., and Alekseyev, A. (2014). Sacrifice as the ideal hunt: a cosmological explanation for the origin of reindeer domestication. Journal of the Royal Anthropological Institute, 21(1), 1-23. doi: 10.1111/1467-9655.12142

Zeder, M. A., Emshwiller, E., Smith, B. D., and Bradley, D. G. (2006). Documenting domestication: the intersection of genetics and archaeology. Trends in Genetics, 22(3), 139155. doi: 10.1016/j.tig.2006.01.007

Zeder, M. A. (2006). Documenting domestication: new genetic and archaeological paradigms. Berkeley: University of California Press.

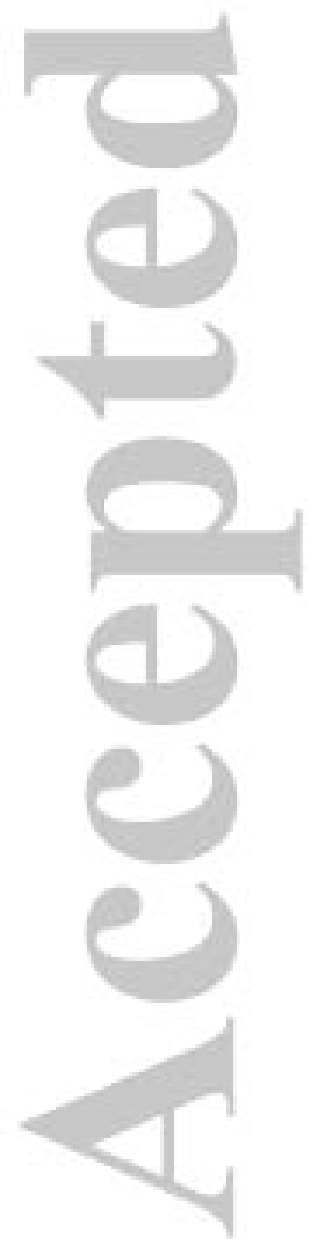



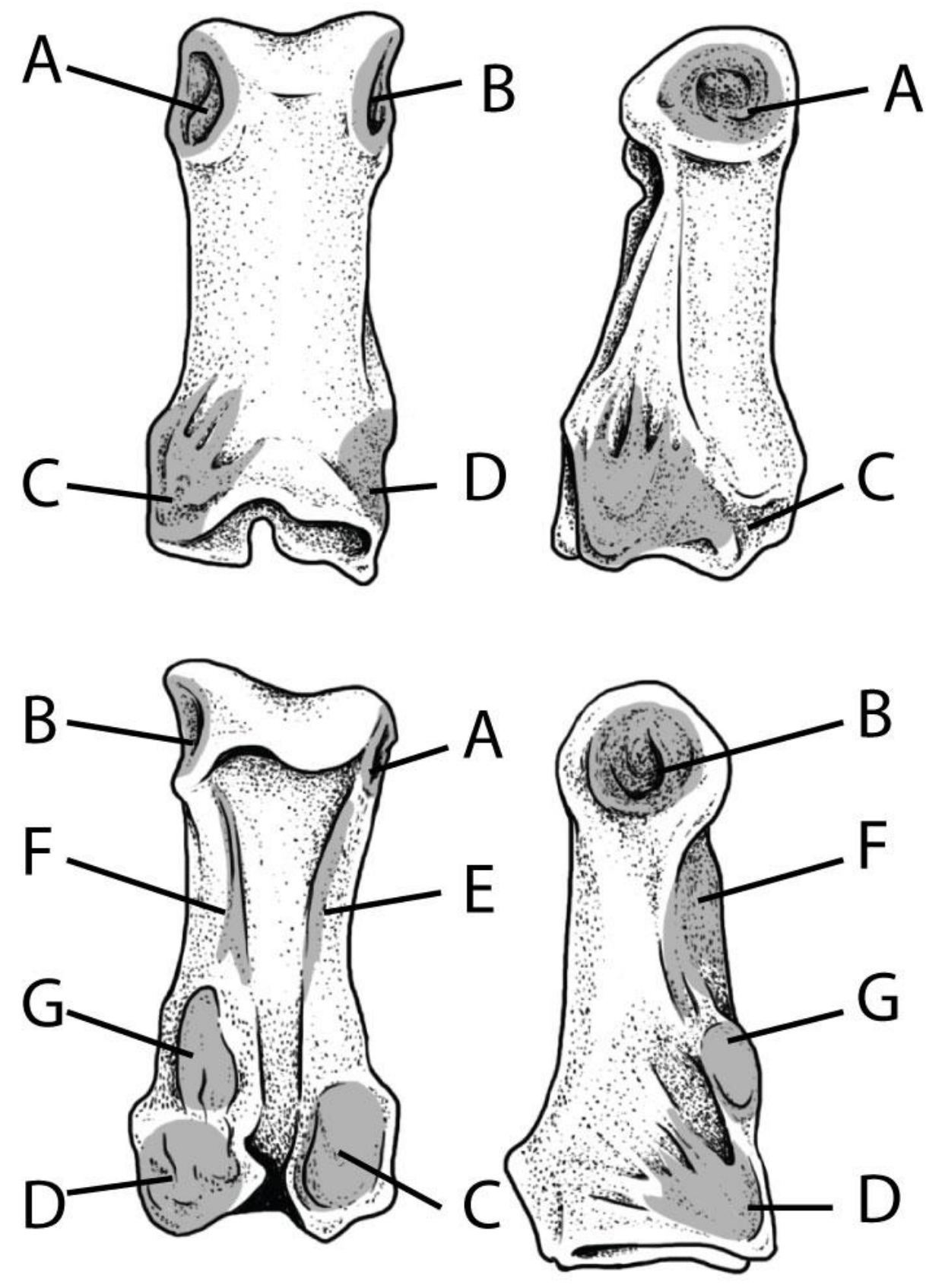

Fig 1. Entheseal sites scored on PI. Illustrations by E. Hull.

A: Lateral collateral metacarpo/metatarsophalangeal ligament; B: Medial collateral metacarpo/metatarsophalangeal ligament; $\mathrm{C}$ : Lateral collateral proximal interphalangeal ligament; D: Medial collateral proximal interphalangeal ligament; E: Distal annular ligament of PI; F: Distal annular ligament of PI; G: Proximal annular ligament of PI 


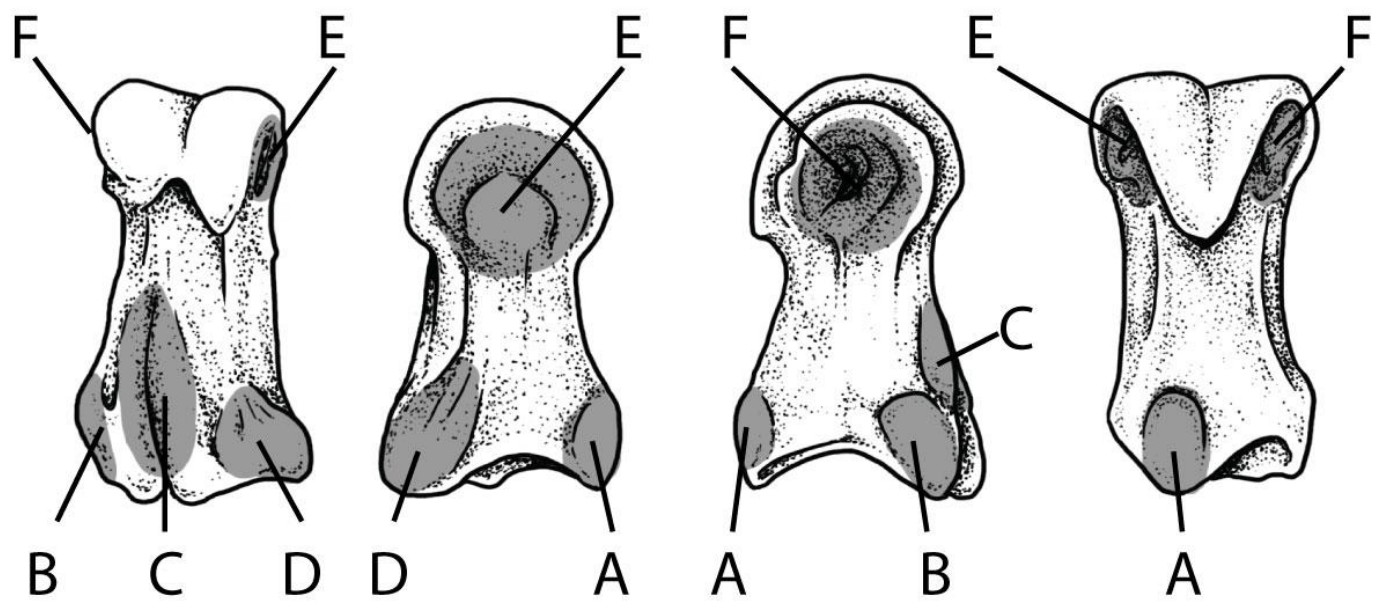

Fig 2. Fig. 2: Entheseal sites scored on PII. Illustrations by E. Hull.

A: Extensor tuberosity; B: Lateral interphalangeal distal collateral ligament; C: Flexor tuberosity; D: Medial interphalangeal distal collateral ligament; E: Medial interphalangeal proximal collateral ligament; F: Lateral interphalangeal proximal collateral ligament 

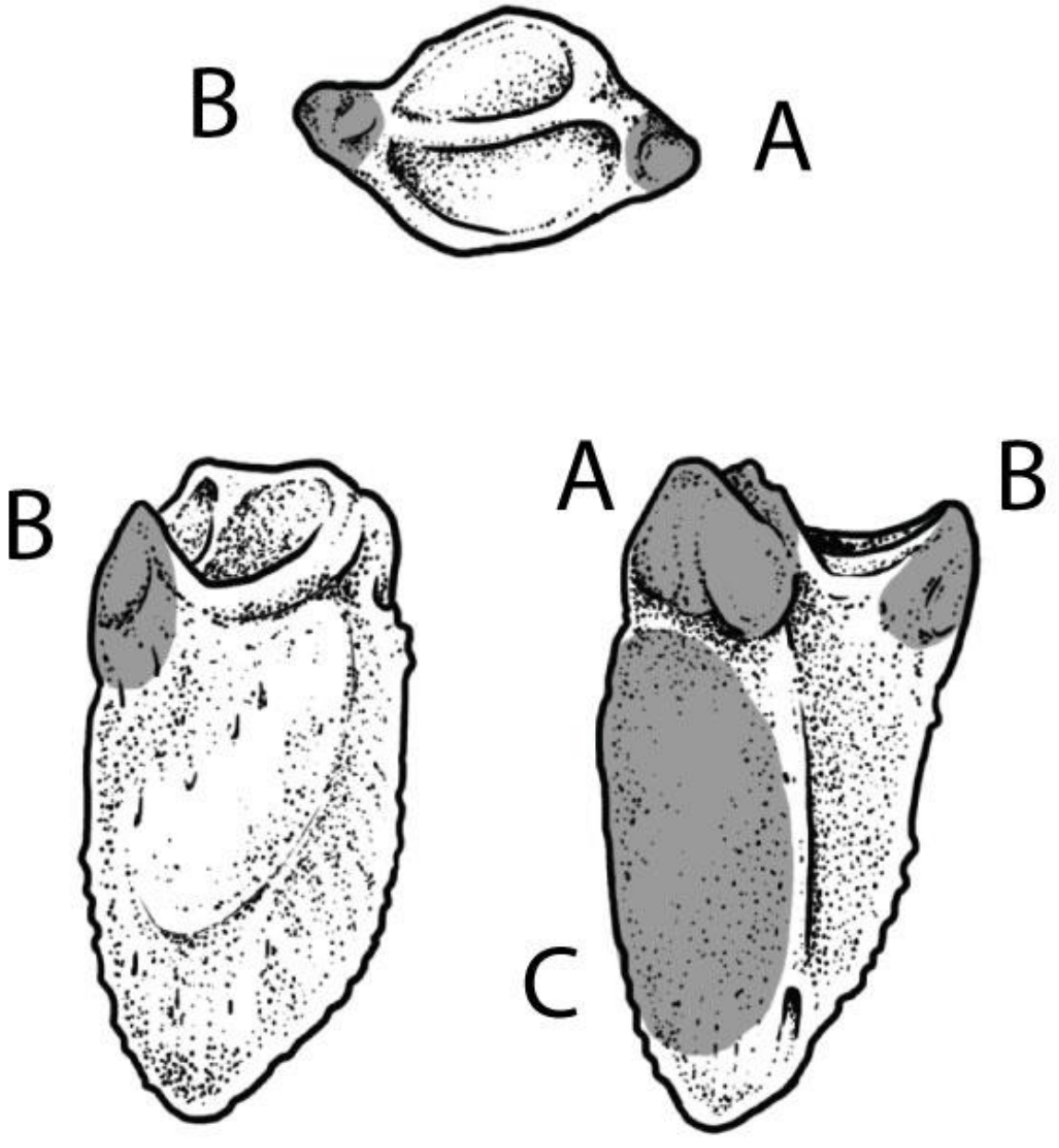

Fig 3. Fig. 2: Entheseal sites scored on PIII. Illustrations by E. Hull.

A: Flexor tubercle (deep flexor tendon); B: Extensor tuberosity (common/long extensor tendon); C: Soleal surface (deep flexor tendon) 
Table 1. Numbers of Specimens and Individuals

\begin{tabular}{|l|l|l|l|}
\hline & PI & PII & PIII \\
\hline R.t. tarandus & $\mathrm{n}=132,23$ individuals & $\mathrm{n}=125,23$ individuals & $\mathrm{n}=123,23$ individuals \\
\hline R.t. fennicus & $\mathrm{n}=23,8$ individuals & $\mathrm{n}=9,7$ individuals & $\mathrm{n}=10,7$ individuals \\
\hline
\end{tabular}


Table 2. Pooled Phalanges compared by Ecotype

\begin{tabular}{|c|c|c|c|c|c|c|c|c|}
\hline Site & Anatomical Point & $\begin{array}{l}\text { Pooled difference } \\
\text { between } \\
\text { R.t.tarandus ( } n= \\
\text { 132) and } R . t \text {. } \\
\text { fennicus( } n=23 \text { ) PI }\end{array}$ & $\mathbf{U}$ & $\begin{array}{l}\text { Effect } \\
\text { Size } \\
\text { (Cohen's } \\
\text { d) }\end{array}$ & Subspecies & Mean & Median & SD \\
\hline \multirow[t]{2}{*}{ A } & \multirow{2}{*}{$\begin{array}{l}\text { Lateral collateral } \\
\text { metacarpo/metatarsophalangeal } \\
\text { ligament }\end{array}$} & \multirow[t]{2}{*}{$p<.001$} & \multirow[t]{2}{*}{893} & \multirow[t]{2}{*}{0.781} & R.t.tarandus & 1.000 & 1.000 & 0.798 \\
\hline & & & & & R.t.fennicus & 1.609 & 2.000 & 0.656 \\
\hline \multirow[t]{2}{*}{ B } & \multirow{2}{*}{$\begin{array}{l}\text { Medial collateral } \\
\text { metacarpo/metatarsophalangeal } \\
\text { ligament }\end{array}$} & \multirow[t]{2}{*}{$p<.001$} & \multirow[t]{2}{*}{810} & \multirow[t]{2}{*}{0.876} & R.t.tarandus & 1.030 & 2.000 & 0.720 \\
\hline & & & & & R.t.fennicus & 1.652 & 2.000 & 0.647 \\
\hline \multirow{2}{*}{ C } & \multirow{2}{*}{$\begin{array}{l}\text { Lateral collateral proximal } \\
\text { interphalangeal ligament }\end{array}$} & \multirow[t]{2}{*}{$p=.083$} & \multirow[t]{2}{*}{1206} & \multirow[t]{2}{*}{0.390} & R.t.tarandus & 1.015 & 1.000 & 0.738 \\
\hline & & & & & R.t.fennicus & 1.304 & 1.000 & 0.765 \\
\hline \multirow[t]{2}{*}{$\mathrm{D}$} & \multirow{2}{*}{$\begin{array}{l}\text { Medial collateral } \\
\text { proximal interphalangeal } \\
\text { ligament }\end{array}$} & \multirow[t]{2}{*}{$p=.208$} & \multirow[t]{2}{*}{1293} & \multirow[t]{2}{*}{-0.249} & R.t.tarandus & 1.158 & 1.000 & 0.833 \\
\hline & & & & & R.t.fennicus & 0.957 & 1.000 & 0.638 \\
\hline \multirow[t]{2}{*}{$E$} & \multirow[t]{2}{*}{ Distal annular ligament of PI } & \multirow[t]{2}{*}{$p<.001$} & \multirow[t]{2}{*}{787} & \multirow[t]{2}{*}{0.959} & R.t.tarandus & 0.842 & 1.000 & 0.716 \\
\hline & & & & & R.t.fennicus & 1.522 & 2.000 & 0.665 \\
\hline \multirow[t]{2}{*}{$\mathbf{F}$} & \multirow{2}{*}{ Distal annular ligament of PI } & $p<.001$ & 551 & 1.266 & R.t.tarandus & 0.955 & 1.000 & 0.767 \\
\hline & & & & & R.t.fennicus & 1.870 & 2.000 & 0.344 \\
\hline G & Proximal annular ligament of $\mathrm{PI}$ & $p=.346$ & 1353 & 0.202 & R.t.tarandus & 1.105 & 1.000 & 0.761 \\
\hline & & & & & R.t.fennicus & 1.261 & 1.000 & 0.810 \\
\hline Site & Anatomical Point & $\begin{array}{l}\text { Pooled difference } \\
\text { between } \\
\text { R.t.tarandus ( } n= \\
\text { 125) and } R . t . \\
\text { fennicus }(n=9 \text { ) PII }\end{array}$ & $\mathbf{U}$ & $\begin{array}{l}\text { Effect } \\
\text { Size } \\
\text { (Cohen's } \\
\text { d) }\end{array}$ & Subspecies & Mean & Median & SD \\
\hline$A$ & Extensor tuberosity & $p=.178$ & 390 & 0.551 & R.t.tarandus & 1.144 & 1.000 & 0.748 \\
\hline & & & & & R.t.fennicus & 1.556 & 2.000 & 0.726 \\
\hline B & Lateral interphalangeal distal & $p=.929$ & 525 & 0.163 & R.t.tarandus & 1.312 & 2.000 & 0.817 \\
\hline & collateral ligament & & & & R.t.fennicus & 1.444 & 2.000 & 0.726 \\
\hline $\mathrm{C}$ & Flexor tuberosity & $p=.343$ & 449 & -0.336 & R.t.tarandus & 1.376 & 2.000 & 0.790 \\
\hline & & & & & R.t.fennicus & 1.111 & 1.000 & 0.782 \\
\hline D & Medial interphalangeal distal & $p=.111$ & 451 & 0.352 & R.t.tarandus & 1.064 & 1.000 & 0.759 \\
\hline & collateral ligament & & & & R.t.fennicus & 1.333 & 2.000 & 0.866 \\
\hline $\mathrm{E}$ & Medial interphalangeal proximal & $p=.791$ & 551 & -0.041 & R.t.tarandus & 0.576 & 1.000 & 0.496 \\
\hline & collateral IIgament & & & & R.t.fennicus & 0.556 & 1.000 & 0.527 \\
\hline $\mathrm{F}$ & Lateral interphalangeal proximal & $p=.702$ & 494 & 0.179 & R.t.tarandus & 1.304 & 1.000 & 0.775 \\
\hline & collateral ligament & & & & R.t.fennicus & 1.444 & 2.000 & 0.882 \\
\hline Site & Anatomical Point & $\begin{array}{l}\text { Pooled difference } \\
\text { between } \\
\text { R.t.tarandus ( } n= \\
\text { 123) and } R . t . \\
\text { fennicus ( } n=10 \text { ) } \\
\text { PIII }\end{array}$ & $\mathbf{U}$ & $\begin{array}{l}\text { Effect } \\
\text { Size } \\
\text { (Cohen's } \\
\text { d) }\end{array}$ & Subspecies & Mean & Median & SD \\
\hline A & Flexor tubercle (deep flexor & $p=.045$ & 396 & 0.650 & R.t.tarandus & 1.016 & 1.000 & 0.735 \\
\hline & tendon) & & & & R.t.fennicus & 1.500 & 2.000 & 0.850 \\
\hline B & Extensor tuberosity & $p=.002$ & 275 & 1.055 & R.t.tarandus & 0.862 & 1.000 & 0.813 \\
\hline & (common/long extensor tendon) & & & & R.t.fennicus & 1.700 & 2.000 & 0.483 \\
\hline C & Soleal surface (deep flexor & $p=.033$ & 380 & 0.716 & R.t.tarandus & 1.033 & 1.000 & 0.809 \\
\hline & tendon) & & & & R.t.fennicus & 1.600 & 2.000 & 0.516 \\
\hline
\end{tabular}

This article is protected by copyright. All rights reserved. 
Table 3. Forelimb and Hindlimb compared by Ecotype

\begin{tabular}{|c|c|c|c|c|c|c|c|c|}
\hline Site & Anatomical Point & $\begin{array}{l}\text { R.t.tarandus ( } n= \\
66 \text { ) v. R.t. } \\
\text { fennicus ( } n=11 \text { ) } \\
\text { PI forelimb }\end{array}$ & $\mathbf{U}$ & $\begin{array}{l}\text { Effect Size } \\
\text { (Cohen's d) }\end{array}$ & Subspecies & Mean & Median & SD \\
\hline \multirow[t]{2}{*}{$\bar{A}$} & \multirow{2}{*}{$\begin{array}{l}\text { Lateral collateral } \\
\text { metacarpo/metatarsophalangeal } \\
\text { ligament }\end{array}$} & \multirow[t]{2}{*}{$p=.013$} & \multirow[t]{2}{*}{202} & \multirow[t]{2}{*}{0.826} & R.t.tarandus & 1.000 & 1.000 & 0.784 \\
\hline & & & & & R.t.fennicus & 1.636 & 2.000 & 0.674 \\
\hline \multirow[t]{2}{*}{ B } & \multirow{2}{*}{$\begin{array}{l}\text { Medial collateral } \\
\text { metacarpo/metatarsophalangeal } \\
\text { ligament }\end{array}$} & \multirow[t]{2}{*}{$p=.006$} & \multirow[t]{2}{*}{187} & \multirow[t]{2}{*}{0.918} & R.t.tarandus & 0.955 & 1.000 & 0.753 \\
\hline & & & & & R.t.fennicus & 1.636 & 2.000 & 0.674 \\
\hline \multirow[t]{2}{*}{$\mathrm{C}$} & \multirow{2}{*}{$\begin{array}{l}\text { Lateral collateral proximal } \\
\text { interphalangeal ligament }\end{array}$} & \multirow[t]{2}{*}{$p=.290$} & \multirow[t]{2}{*}{294.5} & \multirow[t]{2}{*}{0.33} & R.t.tarandus & 1.106 & 1.000 & 0.767 \\
\hline & & & & & R.t.fennicus & 1.364 & 1.000 & 0.809 \\
\hline \multirow[t]{2}{*}{ D } & \multirow{2}{*}{$\begin{array}{l}\text { Medial collateral } \\
\text { proximal interphalangeal } \\
\text { ligament }\end{array}$} & \multirow[t]{2}{*}{$p=.003$} & \multirow[t]{2}{*}{187.5} & \multirow[t]{2}{*}{-0.878} & R.t.tarandus & 1.591 & 2.000 & 0.679 \\
\hline & & & & & R.t.fennicus & 1.000 & 1.000 & 0.632 \\
\hline \multirow[t]{2}{*}{$\mathrm{E}$} & \multirow{2}{*}{ Distal annular ligament of PI } & \multirow[t]{2}{*}{$p=.040$} & \multirow[t]{2}{*}{234} & \multirow[t]{2}{*}{0.725} & R.t.tarandus & 0.697 & 1.000 & 0.656 \\
\hline & & & & & R.t.fennicus & 1.182 & 1.000 & 0.751 \\
\hline \multirow[t]{2}{*}{$\mathbf{F}$} & \multirow[t]{2}{*}{ Distal annular ligament of PI } & \multirow[t]{2}{*}{$p<.001$} & \multirow[t]{2}{*}{80.5} & \multirow[t]{2}{*}{1.675} & R.t.tarandus & 0.773 & 1.000 & 0.791 \\
\hline & & & & & R.t.fennicus & 1.909 & 2.000 & 0.302 \\
\hline $\bar{G}$ & Proximal annular ligament of PI & $p=.572$ & 326.5 & 0.174 & R.t.tarandus & 1.227 & 2.000 & 0.780 \\
\hline & & & & & R.t.fennicus & 1.364 & 1.000 & 0.809 \\
\hline Site & Anatomical Point & $\begin{array}{l}\text { R.t.tarandus ( } n= \\
\text { 67) v. } R . t . \\
\text { fennicus }(n=12) \\
\text { PI hindlimb }\end{array}$ & $U$ & $\begin{array}{l}\text { Effect Size } \\
\text { (Cohen's d) }\end{array}$ & Subspecies & Mean & Median & SD \\
\hline $\bar{A}$ & Lateral collateral & $p=.023$ & 245 & 0.732 & R.t.tarandus & 1.000 & 1.000 & 0.816 \\
\hline & $\begin{array}{l}\text { metacarpo/metatarsophalangeal } \\
\text { ligament }\end{array}$ & & & & R.t.fennicus & 1.583 & 2.000 & 0.669 \\
\hline B & Medial collateral & $p=.008$ & 219 & 0.827 & R.t.tarandus & 1.106 & 1.000 & 0.682 \\
\hline & $\begin{array}{l}\text { metacarpo/metatarsophalangeal } \\
\text { ligament }\end{array}$ & & & & R.t.fennicus & 1.667 & 2.000 & 0.651 \\
\hline C & Lateral collateral proximal & $p=.152$ & 305 & 0.457 & R.t.tarandus & 0.925 & 1.000 & 0.703 \\
\hline & interphalangeal ligament & & & & R.t.fennicus & 1.250 & 1.000 & 0.754 \\
\hline $\mathrm{D}$ & Medial collateral proximal & $p=.360$ & 340 & 0.251 & R.t.tarandus & 0.731 & 1.000 & 0.750 \\
\hline ill & interphalangeal ligament & & & & R.t.fennicus & 0.917 & 1.000 & 0.699 \\
\hline $\mathrm{E}$ & Distal annular ligament of $\mathrm{PI}$ & $p<.001$ & 156 & 1.197 & R.t.tarandus & 0.985 & 0.000 & 0.749 \\
\hline & & & & & R.t.fennicus & 1.833 & 1.000 & 0.389 \\
\hline $\mathbf{F}$ & Distal annular ligament of PI & $p=.003$ & 201 & 0.953 & R.t.tarandus & 1.134 & 0.000 & 0.776 \\
\hline & 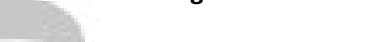 & & & & R.t.fennicus & 1.833 & 1.000 & 0.389 \\
\hline G & Proximal annular ligament of PI & $p=.436$ & 349 & 0.244 & R.t.tarandus & 0.985 & 0.000 & 0.728 \\
\hline & & & & & R.t.fennicus & 1.167 & 0.000 & 0.835 \\
\hline
\end{tabular}

This article is protected by copyright. All rights reserved. 
Table 4. Forelimb and Hindlimb divided by Ecotype

\begin{tabular}{|c|c|c|c|c|c|c|c|c|}
\hline Site & Anatomical Point & $\begin{array}{l}\text { R.t. tarandus } \\
\text { PI } \\
\text { Forelimb } \\
\text { (n= 66) v. } \\
\text { hindlimb } \\
\text { (n=67) }\end{array}$ & U & $\begin{array}{l}\text { Effect } \\
\text { Size } \\
\text { (Cohen's } \\
\text { d) }\end{array}$ & Limb & Mean & Median & SD \\
\hline \multirow[t]{2}{*}{ A } & \multirow{2}{*}{$\begin{array}{l}\text { Lateral collateral metacarpo/metatarsophalangeal } \\
\text { ligament }\end{array}$} & \multirow[t]{2}{*}{$p=1.000$} & \multirow[t]{2}{*}{2211} & \multirow[t]{2}{*}{0.000} & Thoracic & 1.000 & 1.000 & 0.784 \\
\hline & & & & & Pelvic & 1.000 & 1.000 & 0.816 \\
\hline \multirow[t]{2}{*}{$B$} & \multirow{2}{*}{$\begin{array}{l}\text { Medial collateral metacarpo/metatarsophalangeal } \\
\text { ligament }\end{array}$} & \multirow[t]{2}{*}{$p=.234$} & \multirow[t]{2}{*}{1936} & \multirow[t]{2}{*}{-0.211} & Thoracic & 0.955 & 1.000 & 0.753 \\
\hline & & & & & Pelvic & 1.106 & 1.000 & 0.682 \\
\hline \multirow[t]{2}{*}{ C } & \multirow{2}{*}{$\begin{array}{l}\text { Lateral collateral proximal } \\
\text { interphalangeal ligament }\end{array}$} & \multirow[t]{2}{*}{$p=.157$} & \multirow[t]{2}{*}{1918} & \multirow[t]{2}{*}{0.246} & Thoracic & 1.106 & 1.000 & 0.767 \\
\hline & & & & & Pelvic & 0.925 & 1.000 & 0.703 \\
\hline \multirow{2}{*}{ D } & \multirow{2}{*}{$\begin{array}{l}\text { Medial collateral proximal } \\
\text { interphalangeal ligament }\end{array}$} & \multirow[t]{2}{*}{$p<.001$} & \multirow[t]{2}{*}{959} & \multirow[t]{2}{*}{1.201} & Thoracic & 1.591 & 2.000 & 0.679 \\
\hline & & & & & Pelvic & 0.731 & 1.000 & 0.750 \\
\hline \multirow[t]{2}{*}{$\mathrm{E}$} & \multirow{2}{*}{ Distal annular ligament of $\mathrm{PI}$} & \multirow[t]{2}{*}{$p=.025$} & \multirow[t]{2}{*}{1751} & \multirow[t]{2}{*}{-0.409} & Thoracic & 0.697 & 1.000 & 0.656 \\
\hline & & & & & Pelvic & 0.985 & 1.000 & 0.749 \\
\hline \multirow{2}{*}{$F$} & Distal annular ligament of PI & $p=.007$ & 1649 & -0.483 & Thoracic & 0.773 & 1.000 & 0.719 \\
\hline & & & & & Pelvic & 1.134 & 1.000 & 0.776 \\
\hline G & Proximal annular ligament of $\mathrm{PI}$ & $p=.059$ & 1818 & 0.321 & Thoracic & 0.985 & 1.000 & 0.780 \\
\hline & & & & & Pelvic & 1.227 & 1.000 & 0.728 \\
\hline Site & Anatomical Point & \begin{tabular}{l}
\multicolumn{1}{c|}{ R.t. } \\
fennicus PI \\
Forelimb \\
(n=11) v. \\
hindlimb ( $=$ \\
12)
\end{tabular} & $u$ & $\begin{array}{l}\text { Effect } \\
\text { Size } \\
\text { (Cohen's } \\
\text { d) }\end{array}$ & Limb & Mean & Median & SD \\
\hline A & Lateral collateral metacarpo/metatarsophalangeal & $p=.819$ & 62.5 & 0.079 & Thoracic & 1.636 & 2.000 & 0.674 \\
\hline & & & & & Pelvic & 1.583 & 2.000 & 0.669 \\
\hline$B$ & Medial collateral metacarpo/metatarsophalangeal & $p=.936$ & 64.5 & -0.046 & Thoracic & 1.636 & 2.000 & 0.674 \\
\hline 1 & & & & & Pelvic & 1.667 & 2.000 & 0.651 \\
\hline C & Lateral collateral proximal & $p=.688$ & 59.5 & 0.146 & Thoracic & 1.364 & 2.000 & 0.809 \\
\hline & & & & & Pelvic & 1.250 & 1.000 & 0.754 \\
\hline D & Medial collateral proximal & $p=.778$ & 61.5 & 0.128 & Thoracic & 1.000 & 1.000 & 0.632 \\
\hline $\mathrm{r}$ & 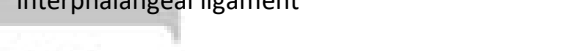 & & & & Pelvic & 0.917 & 1.000 & 0.669 \\
\hline$E$ & Distal annular ligament of PI & $p=.021$ & 33.0 & -1.105 & Thoracic & 1.182 & 1.000 & 0.751 \\
\hline & & & & & \begin{tabular}{l|l} 
Pelvic \\
\end{tabular} & 1.833 & 2.000 & 0.389 \\
\hline $\mathrm{F}$ & Distal annular ligament of PI & $p=.635$ & 61.0 & 0.216 & Thoracic & 1.909 & 2.000 & 0.302 \\
\hline & & & & & \begin{tabular}{l|l} 
Pelvic \\
\end{tabular} & 1.833 & 2.000 & 0.389 \\
\hline G & Proximal annular ligament of PI & $p=.571$ & 57.0 & 0.239 & Thoracic & 1.364 & 2.000 & 0.809 \\
\hline & & & & & Pelvic & 1.167 & 1.000 & 0.835 \\
\hline Site & Anatomical Point & $\begin{array}{l}\text { R.t. } \\
\text { tarandus PII } \\
\text { Forelimb } \\
(n=62) v . \\
\text { hindlimb } \\
(n=63) \\
\end{array}$ & U & $\begin{array}{l}\text { Effect } \\
\text { Size } \\
\text { (Cohen's } \\
\text { d) }\end{array}$ & Limb & Mean & Median & SD \\
\hline A & Extensor tuberosity & $p=.036$ & 1557 & 0.388 & Thoracic & 1.000 & 1.000 & 0.768 \\
\hline & & & & & Pelvic & 1.286 & 1.000 & 0.705 \\
\hline B & Lateral interphalangeal distal collateral & $p=.062$ & 1609 & 0.330 & Thoracic & 1.177 & 2.000 & 0.840 \\
\hline & & & & & Pelvic & 1.444 & 1.000 & 0.778 \\
\hline C & Flexor tuberosity & $p=.028$ & 1556 & -0.399 & Thoracic & 1.532 & 1.000 & 0.718 \\
\hline & & & & & Pelvic & 1.222 & 2.000 & 0.832 \\
\hline $\mathrm{D}$ & & $p=.059$ & 1595 & -0.342 & Thoracic & 1.194 & 1.000 & 0.743 \\
\hline
\end{tabular}




\begin{tabular}{|c|c|c|c|c|c|c|c|c|}
\hline & $\begin{array}{l}\text { Medial interphalangeal distal collateral } \\
\text { ligament }\end{array}$ & & & & Pelvic & 0.937 & 1.000 & 0.759 \\
\hline \multirow[t]{2}{*}{$\mathrm{E}$} & \multirow{2}{*}{$\begin{array}{l}\text { Medial interphalangeal proximal collateral } \\
\text { ligament }\end{array}$} & \multirow[t]{2}{*}{$p=.411$} & \multirow[t]{2}{*}{1810} & \multirow[t]{2}{*}{-0.147} & Thoracic & 0.613 & 1.000 & 0.491 \\
\hline & & & & & Pelvic & 0.540 & 1.000 & 0.502 \\
\hline \multirow[t]{2}{*}{$\mathrm{F}$} & \multirow{2}{*}{$\begin{array}{l}\text { Lateral interphalangeal proximal collateral } \\
\text { ligament }\end{array}$} & \multirow[t]{2}{*}{$p=.100$} & \multirow[t]{2}{*}{1647} & \multirow[t]{2}{*}{-0.297} & Thoracic & 1.419 & 1.000 & 0.737 \\
\hline & & & & & Pelvic & 1.190 & 2.000 & 0.800 \\
\hline
\end{tabular}

